\title{
From Selection To Termination: An Investigation Of Advertising Agency/Client Relationships
}

Ulku Yuksel, (E-mail: u.yuksel@econ.usyd.edu.au ), The University of Sydney, Australia

Catherine Sutton-Brady, (E-mail: c.sutton-brady@econ.usyd.edu.au), The University of Sydney, Australia

\begin{abstract}
It is a fact of corporate life that firms now and again change their advertising agencies. Therefore the first objective of this study is to analyze the mixed and overlapping dimensions of the selection, evaluation, and termination processes. The second objective is to identify the differences that exist in evaluation criteria by comparing both parties to the relationship. This exploratory and descriptive study attempts to understand the interactions from a theoretical background of organizational relations literature, namely, transaction cost theory, network theory, and resource based view $(R B V)$. An important managerial implication of this study is that it gives a clearer picture of similarities and discrepancies in the views held by both parties in the client firm and advertising agency context. The results of this study indicate that it is important for both parties to understand that both the client and the agency may have different reasons for making their respective decisions.
\end{abstract}

\section{INTRODUCTION}

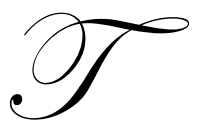

here are various early studies in the advertising literature about advertising agency and client relationship (Delener 1996), and the selection (Waller and Louviere 2002), evaluation (Morrison and Haley 2003; Na, Marshall and Son 1999) and change criteria of advertising agencies' by the client firms. Despite the variety of the studies in relation to these processes, however, the criteria for these three practices are complex, mixed, and overlapping in these earlier studies. Therefore, this paper first analyzes and divides the mixed and overlapping dimensions in selection, evaluation, and termination processes. Second, this study demonstrates the different kinds of perceptions on evaluation dimension both from the firm's and agency's side. To be able to build up a sound relationship, however, these evaluation dimensions should be identified and recognized as the same by both parties. Third, previous studies do not provide theoretical background for the explanations of their results, nor do they support inter-organizational relationships with theories borrowed from different disciplines. This study explicates the theoretical background of the relationship between the firm and the agency by means of theories borrowed from organizational relations literature, including transaction cost theory, which explains the switching costs of agencies for a client firm and vise versa, network theory and the resource-based view (RBV).

In early stages of advertising evaluation, activities related with advertising and promotion in general were taken as lavish and extravagant, and as such avoidable by the majority of the firms. Additionally for many of them advertising has been among the first company expense cut during hard financial times. Promotional dollars were considered superfluous, and firms were reluctant to assign and distribute a substantial share of their budget to such an excessive, preventable, and luxurious expenditure. With the ever-increasing competition in business settings, enhanced technology, and globalization, firms have begun to put more importance on promotion and advertising activities. Now, almost all companies are in a business-to-business relationship with advertising agencies and allot huge shares of their budget to promotional activities depending on their financial resources since advertising is not seen as a cost any more, but as an investment. As a result, effectiveness of advertising activities and agencies becomes a crucial and survival point for more companies. Managers now take more care in obtaining significant and meaningful clues for choosing the right agency to work with. Yet, the agency's performance and effectiveness evaluations are often carried out on a non-objective, informal basis. There are various criteria against which client 
firms' search for the most appropriate advertising partner should be measured, these measurements should help them in making the right decision. Among these are structure and strategy of the firm and the agency, expectations from each other, responsibilities to each other, and finally the satisfaction levels from each other. The purpose of this study is to elaborate a client firm (advertiser)-oriented concept and perspective of effectiveness of advertising agencies by considering all these wide-ranging criteria, i.e. variables.

The first objective of this study is to analyze the mixed and overlapping dimensions of the selection, evaluation, and termination processes. The second objective is to identify the differences that exist in evaluation criteria by comparing both parties to the relationship. This article is organized into five parts. First, marketing theories associated with business- to-business inter-firm relationships and their effects on advertising agency and client firm are discussed. Second, a review of the pertinent literature on selection, evaluation and termination process is undertaken. Third, the research is detailed and the results are discussed. Finally, the discussion and conclusions are outlined.

\section{THEORETICAL BACKGROUND}

The relationships, mutual benefits and risks of the firm and the advertising agency and switching an advertising agency involve channels theories of the marketing and social psychology disciplines, primarily organizational inter-firm relationship theories. Among them are the context and dynamics of "transaction cost economics' and economists' 'rational choice theory' which is adjusted by sociologists' to 'social exchange theory' (relational exchange theory); and network theory and resource dependency; and theory of RBV of the firm. These affect both the client and the agency when the former decides to terminate its contract with its current agency and the latter finds itself in a position to solicit a new account.

Transaction cost theory (Coase 1988) communicates the cost of obtaining some products or services through the market rather than having it supplied from within the firm, which is the case when a client outsources its promotional services to an advertising agency. It is a cost sustained in making economic exchange. Transaction costs are beyond the actual cost of buying the product or service itself. In our case, the non-transaction costs would be the fee or any other sort of compensation of the agency and the cost of the preparation, artwork, and implementation of the promotional material and launching the campaign in the media. Switching an agency will increase transaction costs to both the client and the agency and may sometimes prove significantly and worthlessly high for both parties. That is why it is vital for the business firms not to overlook the transaction costs of a potential transaction (another new relationship with a new agency) before making a rational decision on switching their business partners. Market transaction costs, which would occur when the alliance between the firm and the agency dissolves, could include, (1) search and information costs, that is, costs encountered in determining the new available partners (firm or agency) in deciding which new partner would be the most rational one for value for money etc.; (2) bargaining and decision costs, that is, costs encountered in the agreement and contract phase of the potential new relationship between the firm and the agency; and finally (3) supervision or policing and enforcement costs that is, costs encountered in assuring that the new partner sticks to his promise on the agreement or contract which involves legal procedure costs for both parts.

Economists' 'rational choice theory' presumes that people (executives in organizations) always precisely appraise their benefits and costs in each transaction or behavior, and are always motivated by the possibility of making, increasing and maintaining profit, and decreasing losses, that is, increasing sales, market share, or in the case of advertising agencies, number of clients. Rational choice theory describes the rational person who is always very logical, coherent, consistent and calculative in his decisions and choices. According to this assumption, one can conclude that human behavior is always formal and predictive. Sociologists, however, have adjusted this rational choice theory to 'social exchange theory' considering that human actions involve both rational and non-rational facets, such as "traditional or habitual, emotional or affectual, and other value-oriented actions" (Scott 2000). This explanation would fit into the relationship between the client firm and the agency since the powerful dimensions within this interaction are not only rationale driven according to the literature and the results of our research. 
Resource dependency is an open-system theory at the organizational unit level that states that "all organizations exchange resources with the environment to survive" (Scott 2000 p.114). "The need to acquire resources creates dependencies between organizations and external units" (p. 114), which in due course can cause political problems that require political solutions. In this perspective, organizations have choice over their own fate. Managers should acquire resources without creating difficult dependencies." (p.114). RBV, as a theory of competitive advantage, holds that firms can earn sustainable returns if they have superior resources, which are protected by preventing their diffusion throughout industry. RBV assumes that the desired outcome of managerial effort within the firm is sustainable competitive advantage, which would allow the firm to earn economic rents or above-average returns. This can be achieved with supra normal, excellent promotional strategies and campaigns for the firm by hiring the right and appropriate agency as the communications partner. Such an alliance would serve as a precious resource, indeed as a partner to get sustainable competitive advantage. In turn, this is the focus of firms to achieve and sustain advantages over competitors. RBV declares that possession of key resources should have characteristics such as value, barriers, duplication and appropriability (Fahy and Smithee 1999). A superb campaign will create a unique promotional sustainable competitive advantage and would add to a client firm and its products and brands astonishing brand knowledge, and accordingly brand equity.

\section{SELECTION AND EVALUATION CRITERIA}

It is a fact of corporate life that firms now and again change their advertising agencies. A range of aspects induces firms' managers to initiate new relationships with advertising agencies. One of the major aspects is in relation with the firm's financial performances. However, it is significant to find out whether new relationships result in an increase in the market value of the firm (Mathur and Mathur 1996). Another important aspect, which motivates the managers to re-evaluate their advertising and the agency, is in relation to downturn in economic conditions (Dowling 1994). In addition, the variety and depth of services provided by the agencies is an important aspect. Large firms take the availability and benefits of marketing services, provided by advertising agencies such as consumer research, copy testing, audience measurement, and effectiveness studies, for granted (Dart 1980). This kind of variety of services cannot be met by small advertising agencies that are also called boutique agencies and employ or are founded by very talented creative people. Hence, for small agencies the chance to be selected by large firms is quite limited. Due to their size they are not even considered and do not make the to-be-evaluated lists.

\section{LOSING CLIENTS FROM AGENCY PERSPECTIVE}

Evaluation criteria on changing agencies, in the advertising literature from advertising agency's perspective, have been posited as unrealistic demands by the client; poor communication; performance or service (Na, Marshall and Son 1999); personality conflicts; personnel changes; changes in the size of the client firm or the agency; conflicts of interests; changes in the client's corporate or marketing strategy; declining sales (Flandin, Martin and Simkin 1992); changes in policies; and finally conflicting compensation philosophies (Belch and Belch 1999).

Selection and evaluation criteria in the advertising literature have been classified by various authors with several dimensions (Dowling 1994; Helgesen 1994; Henke 1995; Kaynak et al. 1995; Luk and Yip 1996; Marshall and Bong Na 1994; Jannic and Zabkar 1998; West 1997; Willis 1992). We have summarized them in tables 1-3 to assist ease of reading.

\section{RESEARCH OBJECTIVE}

Based on the literature the main objectives of the study in a managerial context can be summarized in two main points. Firstly to understand more deeply the selection, evaluation and switching criteria in the relationship, and secondly to gain more knowledge about the client and agency in terms of business demographics, clients' expectations from the agency, client's main complaints about the agencies, intentions regarding the future of their relationships, and their perceptions concerning firm-agency relationship. 
Table 1a: Selection Criteria From Client's Viewpoint

\begin{tabular}{|l|l|}
\hline Referral by satisfied clients & $\begin{array}{l}\text { (Marshall and Bong Na 1994; Jannic and Zabkar 1998; Willis } \\
1992)\end{array}$ \\
\hline Personal solicitation & (Marshall and Bong Na 1994) \\
\hline Qualifications of the agency personnel & (Marshall and Bong Na 1994; West 1997) \\
\hline Price of services (agency cost) & (Marshall and Bong Na 1994; Luk and Yip 1996) \\
\hline Age of agency & (Dowling 1994) \\
\hline Good track report in Creative awards & $\begin{array}{l}\text { (Dowling 1994; West 1997; Jannic and Zabkar 1998; Henke } \\
\text { 1995; Helgesen 1994) }\end{array}$ \\
\hline Reputation of the agency & $\begin{array}{l}\text { (Dowling 1994; Marshall and Bong Na 1994; Jannic and } \\
\text { Zabkar 1998; Helgesen 1994; Luk and Yip 1996; Henke } \\
1995)\end{array}$ \\
\hline $\begin{array}{l}\text { Agency which fits with current marketing strategy of the } \\
\text { client }\end{array}$ & (Dowling 1994; West 1997) \\
\hline Past work & (West 1997) \\
\hline Current work & (West 1997) \\
\hline Equipment of the agency & (Dowling 1994; West 1997) \\
\hline Size of agency & (West 1997; Dowling 1994; Henke 1995; Jannic and Zabkar \\
& 1998) \\
\hline Local agency & (Kaynak et al. 1995) \\
\hline Part of an international group & (Dowling 1994) \\
\hline
\end{tabular}

Table 2a: Changing (Switching) Criteria From Client's Viewpoint

\begin{tabular}{|l|l|}
\hline Senior staff no longer giving sufficient attention & (Dowling 1994) \\
\hline Time for a change & (Dowling 1994; Ghosh and Taylor 1999) \\
\hline Dissatisfaction with agency performance & $\begin{array}{l}\text { (Dowling 1994; Michell and Sanders 1995; Henke 1995; } \\
\text { Lace 1998; Jannic and Zabkar 1998; Ghosh and Taylor 1999; } \\
\text { Beard 2002) }\end{array}$ \\
\hline Key people moved from the agency & (Dowling 1994; Ghosh and Taylor 1999) \\
\hline Disagreement over campaign objective & (Dowling 1994; Ghosh and Taylor 1999) \\
\hline No evidence if the advertisements were working & (Dowling 1994; Ghosh and Taylor 1999) \\
\hline Organizational changes in both agency and client & (Lace 1998; Ghosh and Taylor 1999) \\
\hline Change in client's personnel & (Henke 1995; Ghosh and Taylor 1999) \\
\hline
\end{tabular}

Table 2b: Losing Clients From Agency Perspective

\begin{tabular}{|l|l|}
\hline Unrealistic demands by the client; & (Na, Marshall and Son 1999); \\
\hline Poor communication; & (Na, Marshall and Son 1999); \\
\hline Poor performance or service & (Na, Marshall and Son 1999); \\
\hline Personality conflicts; & (Flandin, Martin and Simkin 1992) \\
\hline Personnel changes; & (Flandin, Martin and Simkin 1992) \\
\hline Changes in the size of the client firm or the agency; & (Flandin, Martin and Simkin 1992) \\
\hline Conflicts of interests; & (Flandin, Martin and Simkin 1992) \\
\hline Changes in the client's corporate or marketing strategy; & (Flandin, Martin and Simkin 1992) \\
\hline Declining sales & (Flandin, Martin and Simkin 1992) \\
\hline Changes in policies & (Belch and Belch 1999) \\
\hline Conflicting compensation philosophies & (Belch and Belch 1999) \\
\hline
\end{tabular}


Table 3: Evaluation Criteria

\begin{tabular}{|c|c|}
\hline Knowledge on client's business, products and markets & $\begin{array}{l}\text { (Dowling 1994; Marshall and Bong Na. 1994; Henke 1995; } \\
\text { West 1997; Jannic and Zabkar 1998; Griffin et al. 1998); Lace } \\
\text { 1998; Beard 2002) }\end{array}$ \\
\hline $\begin{array}{l}\text { Proactivity, meaning quick reactions of the advertising agency } \\
\text { to the changes in the environment }\end{array}$ & (Kaynak et a.. 1994; Lace 1998; Belch and Belch 1999) \\
\hline Agreement on goals and objectives & (West 1997; Marshall and Bong Na. 1994) \\
\hline $\begin{array}{l}\text { Quality of interaction between advertising agency personnel } \\
\text { and client personnel }\end{array}$ & $\begin{array}{l}\text { (Kaynak et al. 1994; Marshall and Bong Na. 1994; Michell } \\
\text { and Banders 1995; West 1997; Lictenthal and Shani 2000; } \\
\text { Beard 2002) }\end{array}$ \\
\hline Creativity and variety of agency media plans & $\begin{array}{l}\text { (Marshall and Bong Na. 1994; Henke 1995; Lace 1998; } \\
\text { Durkin and Lawlor 2001) }\end{array}$ \\
\hline Creative work that sells & (Helgesen 1994; Griffin et al. 1998; Lace 1998) \\
\hline
\end{tabular}

\section{RESEARCH METHODOLOGY}

\section{Pilot Study}

Initially a pilot study was undertaken to enable the design of the questionnaire to be used in the study. This pilot study was exploratory in nature and utilized semi-structured in-depth interviews with 14 respondents, from different firms and agencies mostly via phone (some were visited in their offices). These in-depth interviews facilitated the exploration of the factors influencing selection, evaluation and termination of the relationship between the firm and the agency.

\section{Main Study}

Subsequently as a result of the pilot study and a review of the extensive literature, a questionnaire encompassing the measures of selection, evaluation, and switching was designed. Respondents were required to evaluate each item using a five-point Likert scale with endpoints of strongly agree / strongly disagree.

Furthermore, we requested standard demographic measures such as gender, age, years of experience in the field, title/position, agency/firm's age and size (in terms of both, the number of employees and revenue) to determine if these variables influence the predictive power of agency selection, evaluation, and switching criteria. Explicitly, standard demographic measures such as gender, age, years of experience in the field, title/position, agency's age and size (in terms of both, the number of employees and revenue) were also included among the remaining questions. For questions that were directed to client firms, the standard demographic measures were also included among the remaining questions. These included gender, age, years of experience in the corporation, and in the field of marketing, advertising, or public relations, title/position, firms age and size (in terms of both, the number of employees and revenue), their current and/or past agency's age and size (in terms of both, the number of employees and revenue).

Respondents in the advertising agencies were asked to nominate a significant account when answering the questions and to base their answers on the relationship with that account. Specifically, for questions that have been directed to advertising agencies, respondents were asked whether there was an account that demanded considerably more of their time than other accounts, such as a major or a primary account. If the agency personnel indicated that she or he works on one or more than one primary account(s) (or on all accounts for senior managers), they were instructed to answer the rest of the questions with this account(s) in mind. If no primary account was indicated, respondents were asked to answer the rest of the questions with their overall account (assignments) in mind. Client firms received the same questionnaire and were asked to nominate the agency they were currently working with or their previous agency. 


\section{Data Collection}

The data for this research were collected, both by mail correspondence, and through structured interviews (face-to-face visits as an executive marketing research method), from a total of 18 firms and agencies (10 firms and 8 agencies) with 61 respondents (49 from firms and 12 from the agencies). From each firm an approximate number of 34 respondents have answered the questionnaire. Based on this data the mean (average) of each question in the questionnaire for each firm, as well as agency has been calculated (therefore, $n 1=10$ and $n 2=8$ instead of 49 and 12) to increase validity and reliability. This was considered necessary since the selection, evaluation and termination decisions with an agency are made by these influencers and members of the buying centers of agency services in those firm. It also allows us to determine the perceptions of the agency's key personnel regarding the criteria, which they are exposed to when they solicit a new account to be selected, work with a firm, or confront the position of being terminated by their client firm. The term "client" used in this paper refers to corporate firms.

The sample was chosen from private sector firms from different industry sectors. All 61 respondents were either managers and professionals having decision making power or direct relationship with the other party, and entitled employees connected to those decisions or have at least influential effects on those decisions in firms (buying center), as well as agency vice presidents, manager's or account executives. This means that participants are professionals working directly or indirectly with the other partner. Specifically, the survey conducted among professionals, executives and managers in corporations (client firms) who varied in title from director of marketing to (marketing) communications manager. In advertising firms, they comprised of advertising director or public relations manager, and advertising agency professionals, who varied in title from managing director to creative director, senior account executive, or executive vice president. The varied cross section of respondents allowed for a deeper understanding of the selection, evaluation and switching criteria they consider and use.

\section{RESULTS}

\section{Client's Perceptions Of Selection Criteria}

As can be seen in Table 4 qualifications of the agency personnel and an agency, which fits with current marketing strategy of the client firm is the number one rated criteria in selecting an agency from client's viewpoint. Other significant variables are the ownership or partnership of the agency by an international group, size of agency and current work of agency, that is what agency has prepared for the specific proposal, and agencies running campaigns with other brands.

Past work of the agency, equipment of the agency, and referral of satisfied clients are not considered as important by clients. And finally, the least important factors for firms in selecting advertising agencies were considered to be creative awards, reputation, price of services, personal solicitation, being a local agency (that is being familiar and fitting easily with the host country's culture), and age of the agency.

\section{Switching Criteria (From Client's Perspective)}

The results in Table 5 show that dissatisfaction with agency performance, and disagreement over campaign objectives are respectively rated as most significant criteria in switching agency from client's viewpoint. Other major variables influencing the switch are senior staff no longer giving sufficient attention to client's business and organizational changes in both the agency and the client.

However, variables such as, the time for change has come, decrease in sales, market share and profit of the client's business, no evidence that the advertisements were working, and change in client's personnel, are not considered as important by clients. Finally, the fact that key people have moved from the agency is considered the least important influence on switching. 


\section{Losing Clients From Agency Perspective}

Within Table 6, we see that changes in the sizes of client firm or agency, poor communication, performance, or service, and personnel changes are rated as most significant criteria in losing clients from the agencies' viewpoint. Other significantly rated variables are changes in the client's corporate or marketing strategy, personality conflicts, and changes in policies. The least important factors from advertising agencies' perspective for losing their clients are declining sales, unrealistic demands by the client, conflicting compensation philosophies, and conflicts of interests.

\section{DISCUSSION AND CONCLUSION}

When we compare the key factors from clients' and agency's points of view, we can conclude that they do not agree on the factors that cause the termination of the relationship. In fact, they only agree on four factors out of ten. First, dissatisfaction with agency performance, which is rated as the number one reason (5.0) for the client to cancel the relationship, for the agency it, is stated as poor communication, performance, and service as the number two with (4.7). Personnel changes, from client's viewpoint, are only the seventh ranked factor influencing a change of agency (2.2), whereas the same factor is the third factor (4.4) from agency's viewpoint, a clear conflict of view. Changes in the size of the client firm or the agency was rated as number one from agency's viewpoint (5.2) and number 4 (3.2) from client's viewpoint along with the naming of organizational changes. However, there is some agreement in ranking of decrease in sales, market share and profit, which from the client's viewpoint is rated as number 6 (2.4), and agency part has rated declining sales as the seventh important factor (2.0).

Table 4, 5, \& 6: Average Of Factors For Selecting Advertising Agencies From Client's Perspective; For Changing (Switching) Advertising Agencies From Client's Perspective; And For Losing Clients From Agency Perspective

\begin{tabular}{|c|c|c|c|c|c|c|c|c|}
\hline $\begin{array}{c}\text { Table 4: Average of } \\
\text { factors for selecting } \\
\text { advertising agencies from } \\
\text { client's perspective }\end{array}$ & & & $\begin{array}{c}\text { Table 5: Average of } \\
\text { factors for changing } \\
\text { (switching) advertising } \\
\text { agencies from client's } \\
\text { perspective }\end{array}$ & & & $\begin{array}{c}\text { Table 6: Average of } \\
\text { factors for losing clients } \\
\text { from agency } \\
\text { perspective }\end{array}$ & & \\
\hline $\begin{array}{l}\text { Qualifications of the } \\
\text { agency personnel }\end{array}$ & 1 & 5.0 & $\begin{array}{l}\text { Dissatisfaction with } \\
\text { agency performance }\end{array}$ & 1 & 5.0 & $\begin{array}{l}\text { Changes in the size of the } \\
\text { client firm or the agency }\end{array}$ & 1 & 5.2 \\
\hline $\begin{array}{l}\text { Agency which fits with } \\
\text { current marketing strategy } \\
\text { of the client }\end{array}$ & 2 & 5.0 & $\begin{array}{l}\text { Disagreement over } \\
\text { campaign objective }\end{array}$ & 2 & 4.4 & $\begin{array}{l}\text { Poor communication, } \\
\text { performance or service }\end{array}$ & 2 & 4.7 \\
\hline $\begin{array}{l}\text { Part of an international } \\
\text { group }\end{array}$ & 3 & 4.6 & $\begin{array}{l}\text { Senior staff no longer } \\
\text { giving sufficient attention }\end{array}$ & 3 & 3.6 & Personnel changes & 3 & 4.4 \\
\hline Size of agency & 4 & 4.4 & $\begin{array}{l}\text { Organizational changes } \\
\text { in both agency and client }\end{array}$ & 4 & 3.2 & $\begin{array}{l}\text { Changes in the client's } \\
\text { corporate or marketing } \\
\text { strategy }\end{array}$ & 4 & 3.8 \\
\hline Current work & 5 & 4.2 & Time for a change & 5 & 2.6 & Personality conflicts & 5 & 3.6 \\
\hline Past work & 6 & 3.8 & $\begin{array}{l}\text { Decrease in sales, market } \\
\text { share and profit of the } \\
\text { client }\end{array}$ & $6 \mathrm{a}$ & 2.4 & Changes in policies & 6 & 3.2 \\
\hline $\begin{array}{l}\text { Equipment/technology of } \\
\text { the agency }\end{array}$ & 7 & 3.6 & $\begin{array}{l}\text { No evidence if the } \\
\text { advertisements were } \\
\text { working }\end{array}$ & $6 \mathrm{~b}$ & 2.4 & Declining sales & 7 & 2.0 \\
\hline $\begin{array}{l}\text { Referral by satisfied } \\
\text { clients }\end{array}$ & 8 & 3.2 & $\begin{array}{l}\text { Change in client's } \\
\text { personnel }\end{array}$ & 7 & 2.2 & $\begin{array}{l}\text { Unrealistic demands by } \\
\text { the client }\end{array}$ & 8 & 1.8 \\
\hline $\begin{array}{l}\text { Good track report in } \\
\text { creative awards }\end{array}$ & 9 & 2.8 & $\begin{array}{l}\text { Key people moved from } \\
\text { the agency }\end{array}$ & 8 & 1.8 & $\begin{array}{l}\text { Conflicting compensation } \\
\text { philosophies }\end{array}$ & 9 & 1.6 \\
\hline Reputation of the agency & 10 & 2.6 & & 9 & 3.1 & Conflicts of interests & 10 & 1.5 \\
\hline $\begin{array}{l}\text { Price of services-value for } \\
\text { money (agency cost) }\end{array}$ & 11 & 2.4 & & & & & 10 & 3.2 \\
\hline Personal solicitation & 12 & 2.0 & & & & & & \\
\hline Local agency & $13 \mathrm{a}$ & 1.6 & & & & & & \\
\hline \multirow[t]{2}{*}{ Age of agency } & $13 \mathrm{~b}$ & 1.6 & & & & & & \\
\hline & 14 & 3.3 & & & & & & \\
\hline
\end{tabular}


The theoretical implication of this study is that it expands the literature review in adding in channels theories of marketing into a promotions setting and environment. An important managerial implication of this study is that it gives a clearer picture of similarities and discrepancies in the views held by both parties in the client firm and advertising agency context. The results of this study indicate that it is important for both parties to understand that both the client and the agency may have different reasons for making their respective decisions. It is envisaged that this study will be expanded to ascertain if these findings hold true in a larger sample.

\section{REFERENCES}

1. Beard F.K. (2002), Exploring the use of advertising agency review consultants, Journal of Advertising Research, 42 (1), 39-51.

2. Belch, G.E. and Belch, M.A. (1999) Advertising and Promotion, 4th edn. Singapore: McGraw-Hill International Editions.

3. Coase, Ronald H. (1988), The Nature of the Firm: Origin, Meaning, Influence, Journal of Law, Economics and Organization, 4 (1), 3-47.

4. Dart, J. (1980), The Advertising agency selection process for small business: Tips from the agencies, Journal of Small Business Management, (Apr), 18 (000002), pp. 1-10.

5. Delener, N. (1996), Beware of globalization: A comparative study of advertising agency-client relationships, Journal of Professional Services Marketing, 14 (1), 167-177.

6. Dowling, G.R.(1994), Searching for a new advertising agency: a client perspective International Journal of Advertising, 13 (3), 229-43.

7. Durkin, M. and Lawlor, M.A. (2001), The implication of the Internet on the advertising agency-client relationship, The Service Industries Journal, 21 (2), 175-90.

8. Fahy, J. and Smithee, A. (1999), Strategic marketing and the resource based view of the firm, AMS, 1-25.

9. Flandin, M.P., Martin, E. and Simkin, L.P. (1992), Advertsisng effectiveness research: a survey of agencies, clients and conflicts, International Journal of Advertsisng, 11 (3), 203-15.

10. Ghosh, B.C. and Taylor, D. (1999), Switching advertising agency: a cross country analysis, Marketing Intelligence \& Planning, 17 (3), 140-6.

11. Griffin, T. McArthur, D., Yamaki T., and Hidalgo P.(1998), Ad agencies', “Ad agencies' performance and role in providing communication service sin Chile, Japan, and the United States, Journal of Advertising Research, 38 (5), 65-75.

12. Helgesen, T. (1994), Advertising awards and advertising agency performance criteria, Journal of Advertising Research, 34 (4), 43-54.

13. Henke, L.L. (1995), A longitudinal analysis of the ad agency-client relationship: predictors of an agency switch, Journal of Advertising Research, 35 (2), 24-31.

14. Jannic, Z. and Zabkar, V. (1998), Establishing marketing relationships in the advertsisng agency business: A transitional economy case Journal of Advertising Research, 38 (6), 27-35.

15. Kaynak, E., Kucukemiroglu, O.and Odabasi, Y. (1995), Advertising agency/client relationships in an advanced developing country, European Journal of Marketing, Bradford, 28 (1), 35-44.

16. Lace, J.M.(1998), evaluating advertising agency performance: actions to enhance the client /agency relationship, Management Research News, 21 (7/8), 47-58.

17. Lictenthal, J.D. and Shani, D. (2000), Fostering client-agency relationships: A Business buying behavior perspectives, Journal of Business Research, 49 (3), 213-28.

18. Luk, S.T.K. and Yip, L.S.C. (1996), The strategic functions of advertising agencies in China: a networking perspective, International Journal of Advertising, 15 (3), 239-50.

19. Marshall, R. and Bong Na, W. (1994), The advertising agency selection process International Journal of Advertising, 13 (3), 217-28.

20. Mathur, L.K. and Mathur, I. (1996) Is value associated with initiating new advertising agency-client relations? Journal of Advertsisng, Fall, 25 (3), pp.1-11.

21. Michell, P.C.N. and Sanders, N.H. (1995), Loyalty in agency-client relations: The impact of the organ Journal of Advertising Research, 35 (2), 9-23. 
22. Morrison, M.A. and Haley, E. (2003), Account Planners' views on how their work is and should be evaluated, Journal of Advertising, 32 (2), 7-16.

23. Na, W., Marshall R., and Son, Y. (1999), An assessment of advertising agency service quality, Journal of Advertising Research,' 39 (3), 33-8.

24. Nachum, L. and Rolle, J.D. (1999), Home country and firm-specific ownership advantages: A study of US, UK and French advertising agencies, International Business Review, 8 (5-6), 633-60.

25. Salancik, G. R. and Pfeffer, J. (1978), A social information processing approach to job attitudes and task design, Administrative Science Quarterly, 23 (2), 224.

26. Scott, John (2000), Rational Choice Theory, http://privatewww.essex.ac.uk, 6/16/2005.

27. Waller, D.S. and Louviere, J. (2002), Advertising agency selection: Developing a framework to model decision states, AMA Conference Proceedings; 13 (Summer), 374-5.

28. West, D.C. (1997), Purchasing professional services: The case of advertising agencies, International Journal of Purchasing and Materials Management, 33 (3), 2-9.

29. Willis, Jr. J.R. (1992), Winning new business: An analysis of advertising agency activities, Journal of Advertising Research, 32 (5), 10-5.

\section{NOTES}




\section{NOTES}

